\title{
Sarcopenic Obesity in Cancer Patients: Focus on Pathogenesis
}

\author{
Wilson Matthew Raffaello ${ }^{1}$, Andree Kurniawan ${ }^{2}$ \\ ${ }^{1}$ Faculty of Medicine, Pelita Harapan University, Tangerang, Indonesia \\ ${ }^{2}$ Department of Internal Medicine, Faculty of Medicine, Pelita Harapan University, Tangerang, Indonesia
}

\section{ARTICLE INFO}

Received : 24 February 2020

Reviewed : 18 May 2020

Accepted : 09 July 2020

\section{Keywords:}

cancer, sarcopenic, obesity,

low muscle mass

\author{
A BSTRACT
}

Introduction: Sarcopenic obesity is an emerging problem in cancer patients. However, this is often difficult to diagnose without the measurement of body composition. Sarcopenic obesity is associated with increased mortality, chemo-toxicity, and other complications in cancer patients. Until now, there is scarce information about sarcopenic obesity in the cancer population.

Method: We identified 1955 articles related to sarcopenic obesity in adult cancer patients using PubMed, PubMed Central, and Cochrane Library databases from January 1, 1989, until January 1 , 2020. Firstly, we screened the titles and abstracts which mentioned sarcopenic and obesity, especially in pathogenesis. 29 articles could proceed to the next step; then, they were screened for the full text. All steps were reviewed by two authors.

Results: At last, they were 9 articles included. Sarcopenic obesity is defined as the coexistence of sarcopenia and obesity, an increase in fat mass in the body. Sarcopenic obesity carried cumulative risks from each of the two individual body compositions. CT-scan offers the highest available precision in determining body composition parameters, especially in the cancer population. Multiple causes and interactions between hormonal changes, aging, disuse, neuronal, poor nutrition, physical inactivity, and low-grade inflammation played roles. Sarcopenic obesity is associated with chemotherapy toxicity. High protein intake should be initiated to ensure adequate protein intake. Resistance training is beneficial in improving muscle mass and strength by focusing on strength training, flexibility, and balance.

Conclusions: Sarcopenic obesity is an emerging problem but is often neglected. Further research needs to be conducted especially in explaining the pathogenesis of sarcopenic obesity. The combination of physical exercise and diet modification is the best management to improve sarcopenia obesity in cancer patients.

\section{INTRODUCTION}

Sarcopenic obesity is a chronic condition characterized by the low skeletal muscle mass and function in the context of excess adiposity and correlates with a decline in physical strength and status. It is a major public health problem with increasing prevalence worldwide. Sarcopenia is a progressive and generalized skeletal muscle disorder that is associated with adverse outcomes (falls, fractures, physical disability, and mortality). The excess adiposity in a sarcopenic person leads to sarcopenic obesity and may exacerbate fat infiltration into the muscle, which further lowers physical function and increases the risk of mortality [1,2]. Thus, both sarcopenia and sarcopenic obesity play a role as an independent prognostic factor in cancer patients [3-5].

Body composition plays a significant role in oncology, referring to the amount and distribution of lean and adipose tissues in the human body. One of the best- known parameters in assessing human anthropometry is body mass index defined as weight/height [2]. Body mass index alone has limitations, especially in the settings of sarcopenic obesity where a patient loses muscle mass but gains adipose tissues. Body composition is an important feature because it affects the distribution of the chemotherapy drugs, thus, affecting efficacy, toxicity in chemotherapy patients, major postoperative complications, and outcomes in cancer patients [6-10].

In conditions related to autoimmune and cancer population, lean body mass is more likely to decrease while fat mass may be preserved or even increased [11]. This may mask the body weight because of the preserved fat mass. It is another thing to consider that fat may infiltrate into muscle and may cause low muscle quality and interfere with muscle performance. These findings are well documented in the elderly where intramuscular and visceral fat increases with aging and subcutaneous fat declines [12-14]. 
The current definition of sarcopenic obesity relies on the combination of obesity and sarcopenia. This makes the diagnosis of sarcopenic obesity is challenging when the definition of obesity and sarcopenia itself is not clear, leading to confusion and preventing inter-study comparisons [15]. In this review, we look further into current articles to evaluate the pathogenesis, diagnosis, impacts, and intervention of sarcopenic obesity in cancer patients.

\section{METHODS}

\section{Search Strategies}

In searching the articles, the researcher used several medical subject headings (MeSH) such as "sarcopenic", "muscle mass", "muscle strength", "obesity", "sarcopenic obesity", "cancer" in three electronic databases (PubMed, PubMed central, Cochrane library) from January 1, 1989, to January 1, 2020 (Table 1). The articles were included in this study if several inclusion criteria below were met: 1. Population included in the studies were cancer patients younger than 60 years old; 2 . Interest: patients with sarcopenic obesity, either low muscle mass diagnosed using CT-scan, DEXA, or BIA and concomitant with BMI $>25 \mathrm{~kg} / \mathrm{m}^{2}$; 3. Comparison or control: non-sarcopenic obesity; 4. Outcomes: the outcome of this study is to evaluate pathogenesis, diagnosis, impact, and intervention;
5. Study design: observational study, interventional study, and article review. Articles were excluded if any exclusion criteria were met: Population with hematological cancer.

\section{Data Extraction}

Several details were extracted, including the author, the country of the study population, inclusion/exclusion criteria, and the type of cancer. The data were also extracted considering the definition of sarcopenia used (low muscle mass and or strength), methods used in defining sarcopenic obesity (CT-scan, DEXA, BIA), and study outcomes (e.g., pathogenesis, diagnosis, impact, and treatment).

Multiple articles were read and appraised based on the Newcastle-Ottawa Validity test. Further information about the characteristics of the studies can be seen in Table 2 .

\section{Quality Assessment and Evidence}

The Newcastle-Ottawa quality assessment of cohort trials was used to measure the risk of bias. Both reviewers assessed the methodological qualities and standards in reporting the outcomes of the studies. The quality of the evidence was graded according to the Agency for Healthcare Research and Quality (AHRQ). The level of evidence was presented as good, fair, and poor. The assessment of the studies can be seen in Table $\mathbf{3}$.

Table 1. Literature search startegy

\begin{tabular}{|c|c|c|}
\hline Database & Keyword & Result \\
\hline PubMed & $\begin{array}{l}\text { (("sarcopenia”[title/abstract] OR “muscle mass"[title/abstract] OR “muscle strength"[title/abstract]) } \\
\text { AND ("obesity”[title/abstract] OR "sarcopenic obesity"[title/abstract]) AND "cancer"[title/abstract]) }\end{array}$ & 132 \\
\hline $\begin{array}{l}\text { Cochrane } \\
\text { library }\end{array}$ & $\begin{array}{l}\text { "sarcopenia" OR "muscle mass" OR "muscle strength" AND "obesity" OR "sarcopenic obesity" } \\
\text { AND "cancer" }\end{array}$ & 35 \\
\hline $\begin{array}{l}\text { PubMed } \\
\text { Central }\end{array}$ & $\begin{array}{l}\text { (Sarcopenic[All Fields] AND ("obesity"[MeSH Terms] OR “obesity"[All Fields]) AND } \\
\text { ("neoplasms"[MeSH Terms] OR "neoplasms"[All Fields] OR "cancer"[All Fields])) }\end{array}$ & 1788 \\
\hline
\end{tabular}

Table 2. Newcastle-Ottawa quality assessment of cohort observational trials

\begin{tabular}{|c|c|c|c|c|c|c|c|c|c|}
\hline & $\begin{array}{c}\text { Prado } \\
2008\end{array}$ & $\begin{array}{l}\text { Malietzis } \\
2016\end{array}$ & $\begin{array}{l}\text { Rier } \\
2017\end{array}$ & $\begin{array}{l}\text { Cushen } \\
2017\end{array}$ & $\begin{array}{c}\text { Tan } \\
2009\end{array}$ & $\begin{array}{c}\text { Rollins } \\
2016\end{array}$ & $\begin{array}{l}\text { Anandavadivelan } \\
2016\end{array}$ & $\begin{array}{l}\text { Palmela } \\
2017\end{array}$ & $\begin{array}{c}\text { Heidelberger } \\
2017\end{array}$ \\
\hline \multicolumn{10}{|l|}{ Selection } \\
\hline Representative of the cohort? & $*$ & $*$ & $*$ & $*$ & $*$ & $*$ & $*$ & $*$ & $*$ \\
\hline Selection of the non-exposed & $*$ & $*$ & $*$ & $*$ & $*$ & $*$ & $*$ & $*$ & $*$ \\
\hline Ascertainment of exposure & $*$ & $*$ & $*$ & $*$ & $*$ & $*$ & $*$ & $*$ & $*$ \\
\hline \multicolumn{10}{|l|}{$\begin{array}{l}\text { Demonstration that outcome } \\
\text { was not present at start of study } \\
\text { Comparability } \\
\text { Comparability on basis } \\
\text { of design or analysis }\end{array}$} \\
\hline \multicolumn{10}{|l|}{ Outcome } \\
\hline Assessment of outcome & $*$ & $*$ & $*$ & $*$ & $*$ & $*$ & $*$ & $*$ & $*$ \\
\hline $\begin{array}{l}\text { Was follow-up long enough } \\
\text { for outcomes to occur }\end{array}$ & $*$ & $*$ & $*$ & $*$ & $*$ & $*$ & $*$ & $*$ & $*$ \\
\hline $\begin{array}{l}\text { Adequacy of follow-up of } \\
\text { cohorts }\end{array}$ & $*$ & $*$ & $*$ & $*$ & $*$ & $*$ & $*$ & $*$ & $*$ \\
\hline Results & Fair & Fair & Fair & Fair & Fair & Fair & Fair & Fair & Fair \\
\hline
\end{tabular}


Table 3. Characteristics of the studies

\begin{tabular}{|c|c|c|c|c|c|c|c|c|}
\hline $\begin{array}{c}\text { Author, } \\
\text { years, country }\end{array}$ & Subjects & $\begin{array}{c}\text { Cancer } \\
\text { sites }\end{array}$ & $\begin{array}{c}\text { CT MRI } \\
\text { DXA BIA }\end{array}$ & $\begin{array}{c}\text { Sarcopenia } \\
\text { criteria }\end{array}$ & $\begin{array}{l}\text { Obesity } \\
\text { criteria }\end{array}$ & $\begin{array}{c}\text { Sarcopenic } \\
\text { obesity \% }\end{array}$ & NDQ & Outcome \\
\hline $\begin{array}{l}\text { Prado } \\
\text { et al, } \\
2008, \\
\text { Canada }\end{array}$ & $\begin{array}{l}\text { Retro- } \\
\text { spective } \\
\text { data }\end{array}$ & $\begin{array}{l}\text { Solid } \\
\text { tumor of } \\
\text { respiratory } \\
\text { tract and } \\
\text { Gastro- } \\
\text { intestinal } \\
\text { tract }\end{array}$ & $\mathrm{CT}$ & $\begin{array}{l}\text { CT L3 SMI: men } \\
\leq 52.4 \mathrm{~cm}^{2} / \mathrm{m}^{2} \\
\text { women } \\
\leq 38.5 \mathrm{~cm}^{2} / \mathrm{m}^{2} \\
\text { cut-offs by } \\
\text { optimal } \\
\text { stratification }\end{array}$ & $\begin{array}{l}\mathrm{BMI} \\
\geq 30 \\
\mathrm{~kg} / \mathrm{m}^{2}\end{array}$ & NA & Fair & $\begin{array}{l}\text { Sarcopenic obesity was associated } \\
\text { with poorer functional status } \\
\text { compared with obese patients } \\
\text { who did not have sarcopenia } \\
\text { ( } p=0.009 \text { ), and was an independent } \\
\text { predictor of survival (hazard ratio } \\
\text { [HR] } 4.2 \text { [95\% Cl } 2.4-7.2] \text {, } \\
p<0.0001 \text { ). }\end{array}$ \\
\hline $\begin{array}{l}\text { Malietzis } \\
\text { et al, } \\
2016 \text {, } \\
\text { UK }\end{array}$ & $\begin{array}{l}\text { Retro- } \\
\text { spective } \\
\text { data }\end{array}$ & $\begin{array}{l}\text { Resectable } \\
\text { colorectal } \\
\text { cancer }\end{array}$ & $\mathrm{CT}$ & $\begin{array}{l}\text { CT L3 SMI: men } \\
\leq 52.4 \mathrm{~cm}^{2} / \mathrm{m}^{2} \\
\text { women } \\
\leq 38.5 \mathrm{~cm}^{2} / \mathrm{m}^{2} \\
\text { cut-offs by } \\
\text { optimal } \\
\text { stratification }\end{array}$ & $\begin{array}{l}\mathrm{BMI} \\
\geq 30 \\
\mathrm{~kg} / \mathrm{m}^{2}\end{array}$ & 9.9 & Fair & $\begin{array}{l}\text { The presence of myosteatosis } \\
\text { was associated with prolonged } \\
\text { primary hospital stay }(P=0.034) \text {, } \\
\text { and myopenic obesity was related } \\
\text { to higher } 30 \text {-day morbidity } \\
(P=0.019) \text { and mortality } \\
(P<0.001) \text { rates. }\end{array}$ \\
\hline $\begin{array}{l}\text { Rier et al, } \\
2017, \\
\text { Netherlands }\end{array}$ & $\begin{array}{l}\text { Retro- } \\
\text { spective } \\
\text { data }\end{array}$ & $\begin{array}{l}\text { Breast } \\
\text { cancer }\end{array}$ & $\mathrm{CT}$ & $\mathrm{SMI} \leq 41 \mathrm{~cm}^{2} / \mathrm{m}^{2}$ & $\begin{array}{l}\text { BMI } \\
\geq 27.5 \\
\mathrm{~kg} / \mathrm{m}^{2}\end{array}$ & 2.3 & Fair & $\begin{array}{l}\text { Low muscle mass (LMM) and } \\
\text { sarcopenic obesity were not } \\
\text { associated with overall survival } \\
\text { (OS) (median OS } 19 \text { vs. } 18 \text { months, } \\
p=0.845 \text { for LMM and } 20 \text { vs. } 18 \\
\text { months, } p=0.481 \text { for sarcopenic } \\
\text { obesity }\end{array}$ \\
\hline $\begin{array}{l}\text { Cushen } \\
\text { et al, } \\
2017 \text {, } \\
\text { Ireland }\end{array}$ & $\begin{array}{l}\text { Retro- } \\
\text { spective } \\
\text { data }\end{array}$ & $\begin{array}{l}\text { Prostate } \\
\text { cancer }\end{array}$ & $\mathrm{CT}$ & $\begin{array}{l}\text { CT L3 SMI: female } \\
<41 \mathrm{~cm}^{2} / \mathrm{m}^{2} ; \\
\text { men }<43(\mathrm{BMI} \\
\left.<25 \mathrm{~kg} / \mathrm{m}^{2}\right) \text { and } \\
<53(\mathrm{BMI} \geq 25)\end{array}$ & $\begin{array}{l}\text { BMI } \\
\geq 27.5 \\
\mathrm{~kg} / \mathrm{m}^{2}\end{array}$ & 12.6 & Fair & $\begin{array}{l}\text { No statistically significant } \\
\text { differences were noted regarding } \\
\text { the occurrence of DLT ( } p=0.827) \\
\text { and sarcopenic obesity was not } \\
\text { predicative of DLT }(p=0.511)\end{array}$ \\
\hline $\begin{array}{l}\text { Tan et al, } \\
2009 \text {, } \\
\text { Canada }\end{array}$ & $\begin{array}{l}\text { Retro- } \\
\text { spective } \\
\text { data }\end{array}$ & $\begin{array}{l}\text { Prostate } \\
\text { cancer }\end{array}$ & $\mathrm{CT}$ & $\begin{array}{l}\text { CT L3 SMI: men } \\
\leq 52.4 \mathrm{~cm}^{2} / \mathrm{m}^{2} ; \\
\text { women } \leq 38.5 \\
\mathrm{~cm}^{2} / \mathrm{m}^{2} ; \text { cut-offs } \\
\text { by optimal } \\
\text { stratification }\end{array}$ & $\begin{array}{l}\mathrm{BMI} \\
\geq 25 \\
\mathrm{~kg} / \mathrm{m}^{2}\end{array}$ & 16.2 & Fair & $\begin{array}{l}\text { Overweight/obese sarcopenia } \\
\text { (hazard ratio, } 2.07 ; 95 \% \text { confidence } \\
\text { interval, } 1.23-3.50 ; \mathrm{P}=0.006 \text { ) were } \\
\text { identified as independent } \\
\text { predictors of survival }\end{array}$ \\
\hline $\begin{array}{l}\text { Rollins } \\
\text { et al, } \\
2016 \text {, } \\
\text { UK }\end{array}$ & $\begin{array}{l}\text { Retro- } \\
\text { spective } \\
\text { data }\end{array}$ & $\begin{array}{l}\text { Pancreatic } \\
\text { cancer }\end{array}$ & $\mathrm{CT}$ & $\begin{array}{l}\text { CT L3 SMI: } \\
\text { female } \\
<41 \mathrm{~cm}^{2} / \mathrm{m}^{2} ; \\
\text { men }<43(\mathrm{BMI} \\
\left.<25 \mathrm{~kg} / \mathrm{m}^{2}\right) \text { and } \\
<53(\mathrm{BMI} \geq 25)\end{array}$ & $\begin{array}{l}\mathrm{BMI} \\
\geq 25 \\
\mathrm{~kg} / \mathrm{m}^{2}\end{array}$ & 25.4 & Fair & $\begin{array}{l}\text { Survival rates is lower in } \\
\text { myosteatotic and sarcopenic } \\
\text { (median } 114 \text { days) and those } \\
\text { who were myosteatotic but not } \\
\text { sarcopenic (median } 131 \text { days) } \\
\text { were lower than in those who } \\
\text { were sarcopenic but not } \\
\text { myosteatotic (median survival } \\
280.5 \text { days) ( } p=0.003 \text { ). }\end{array}$ \\
\hline $\begin{array}{l}\text { Ananda- } \\
\text { vadivelan } \\
\text { et al, } \\
2016 \text {, } \\
\text { Sweden }\end{array}$ & $\begin{array}{l}\text { Retro- } \\
\text { spective } \\
\text { data }\end{array}$ & $\begin{array}{l}\text { Esopha- } \\
\text { geal } \\
\text { cancer }\end{array}$ & $\mathrm{CT}$ & $\begin{array}{l}\text { CT L3 SMI: men } \\
\leq 52.4 \mathrm{~cm}^{2} / \mathrm{m}^{2} ; \\
\text { women } \leq 38.5 \\
\mathrm{~cm}^{2} / \mathrm{m}^{2} ; \text { cut-offs } \\
\text { by optimal } \\
\text { stratification }\end{array}$ & $\begin{array}{l}\mathrm{BMI} \\
\geq 25 \\
\mathrm{~kg} / \mathrm{m}^{2}\end{array}$ & 14 & Fair & $\begin{array}{l}\text { Sarcopenia combined with } \\
\text { overweight/obesity ( } n=10 \text { ) showed } \\
\text { a significantly higher risk } \\
(\mathrm{OR}=5.54 ; 95 \% \mathrm{Cl} 1.12-27.44) \text { of } \\
\text { toxicity compared to non- } \\
\text { sarcopenic obese patients. }\end{array}$ \\
\hline $\begin{array}{l}\text { Palmela } \\
\text { et al, } \\
2017, \\
\text { Portugal }\end{array}$ & $\begin{array}{l}\text { Retro- } \\
\text { spective } \\
\text { data }\end{array}$ & $\begin{array}{l}\text { Gastric } \\
\text { cancer }\end{array}$ & CT & $\begin{array}{l}\text { CT L3 SMI: female } \\
<41 \mathrm{~cm}^{2} / \mathrm{m}^{2} ; \\
\text { men }<43 \\
\left(\mathrm{BMI}<25 \mathrm{~kg} / \mathrm{m}^{2}\right) \\
\text { and }<53 \\
(\mathrm{BMI} \geq 25)\end{array}$ & $\begin{array}{l}\mathrm{BMI} \\
\geq 25 \\
\mathrm{~kg} / \mathrm{m}^{2}\end{array}$ & 10.4 & Fair & $\begin{array}{l}\text { Patients with sarcopenic obesity } \\
\text { showed lower overall survival } \\
\text { (median survival of } 6 \text { months } \\
\text { [95\% confidence interval } \\
\{\mathrm{Cl}\}=3.9-8.5] \text { vs. } 25 \text { months } \\
{[95 \% \mathrm{Cl}=20.2-38.2]}\end{array}$ \\
\hline $\begin{array}{l}\text { Heidel- } \\
\text { berger } \\
\text { et al, } \\
2016, \\
\text { France }\end{array}$ & $\begin{array}{l}\text { Retro- } \\
\text { spective } \\
\text { data }\end{array}$ & Mela-noma & $\mathrm{CT}$ & $\begin{array}{l}\text { CT L3 SMI: men } \\
\leq 52.4 \mathrm{~cm}^{2} / \mathrm{m}^{2} ; \\
\text { women } \\
\leq 38.5 \mathrm{~cm}^{2} / \mathrm{m}^{2} \\
\text { cut-offs by } \\
\text { optimal } \\
\text { stratification }\end{array}$ & $\begin{array}{l}\mathrm{BMI} \\
\geq 25 \\
\mathrm{~kg} / \mathrm{m}^{2}\end{array}$ & 19 & Fair & $\begin{array}{l}\text { Patients who experienced early } \\
\text { ALT, the mean } \mathrm{BMI} \text { was higher } \\
\left(27.9 \text { versus } 24.7 \mathrm{~kg} / \mathrm{m}^{2} ; \mathrm{p}=0.04\right) \text {. } \\
\text { Among the } 32 \text { female patients, } \\
\text { sarcopenic overweight patients had } \\
\text { a } 6.5 \text {-fold increased risk of ALT } \\
\text { ( } 50 \% \text { versus } 7.7 \% ; \mathrm{p}=0.01 \text { ). }\end{array}$ \\
\hline
\end{tabular}

Abbreviations: NOQ: Newcastle-Ottawa validity test; CT: computed tomography; MRI: Magnetic Resonance Imaging; BIA: Bio-Electrical Impedance analysis; DXA: Dual-energy X-ray Absorptiometry; BMI: Body mass Index, SMI: skeletal muscle index; NA: not applicable. 


\section{RESULTS}

\section{Literature Search Results}

We identified 1955 studies evaluating sarcopenia obesity in cancer patients using PubMed, PubMed Central, and Cochrane Library databases. We removed 7 duplicate articles in our findings. The titles and abstracts of the articles were screened, and 1.919 studies were excluded due to full-text unavailability or the articles not related to both sarcopenia and obesity. 20 studies were excluded because of the wrong assessment of sarcopenia or obesity and obscured report of the outcome. At last, there were 9 articles included in this review. Further information can be seen in Figure 1.

\section{Definition of Sarcopenic Obesity}

Multiple definitions of sarcopenia have been proposed, each of which leads to different perspectives. The lack of an accurate definition leads to confusion and difficulties among physicians in diagnosing or assessing patients with suspected sarcopenia. Several anthropometric measurements are being conducted such as mid-arm and calf circumference $[4,15,16]$.

Sarcopenic obesity is defined as the coexistence of sarcopenia and obesity with the latter defined as an increase in fat mass in the body [4]. Sarcopenia normally occurs with aging where a decline of muscle mass is associated with age-related changes in body composition [15]. Combined with the increasing prevalence of obesity, sarcopenia leads to an increased sarcopenic obesity prevalence [17].

According to European Working Group for the study of sarcopenia 2 (EWGSOP2), sarcopenia is defined as a syndrome characterized by decreased muscle mass and function (strength or performance), which increases the risk of disability, poor quality of life, and mortality. As a better predictor than muscle mass, muscle function is used to assess the severity of the sarcopenia [2]. The operational definition of sarcopenia can be seen in Table 4 [2]

Obesity is defined as unhealthy excess body fat that increases the risk of medical illness and mortality [18]. However, no consensus defines obesity cut-off points. The American Association of Clinical Endocrinologists recommends the use of WHO threshold in diagnosing obesity (men $>25 \%$ body fat and women $>35 \%$ body fat) and $\mathrm{BMI} \geq 30 \mathrm{~kg} / \mathrm{m} 2$ and waist circumference (men $>102 \mathrm{~cm}$ and women $>88 \mathrm{~cm}$ ) as a surrogate in diagnosing obesity [19]. The current definition of sarcopenic obesity relies on the combination of obesity and sarcopenia. This makes the diagnosis of sarcopenic obesity is challenging when the definition of obesity and sarcopenia itself is not clear, leading to confusion and preventing inter-study comparisons [15].
Table 4. Operational definition of sarcopenia [2]

Diagnosis based on criteria 1 (probable) and confirmed when criteria 2 are met and considered severe if all of the criterion are all met.

Low muscle strength

Low muscle quantity or quality

Low physical performances

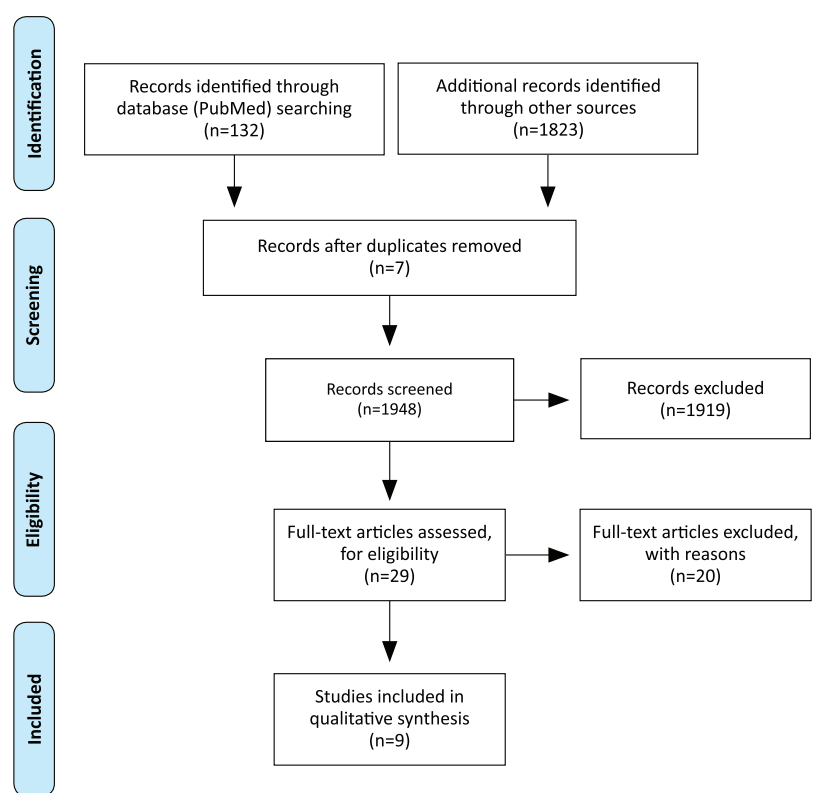

Figure 1. PRISMA literature searched flow diagram

\section{Prevalence of Sarcopenic Obesity in Cancer Patients}

The prevalence of sarcopenic obesity is increasing with age. It also influences physical, metabolic, and cardiovascular functions and is a major concern to nutritionists, geriatricians, and public health officers [20]. Sarcopenic obesity may carry cumulative risks from each of the two individual body compositions. Excess obesity may increase cardiovascular risk, and loss of muscle mass in older individuals may be significantly associated with extended hospital stays which contribute to infectious and non-infectious complications and overall mortality [21-25]. Sarcopenic obesity has a prevalence of $9 \%$ in the population with advanced solid tumors (range $2.3-14.6 \%$ ). It also has a prevalence of $24.7 \%$ (range 5.9-39.2\%) in the population with a body mass index of more than $30 \mathrm{~kg} / \mathrm{m} 2$. The lowest prevalence of sarcopenic obesity is found in the early-stage disease and the highest in the locally advanced or metastatic disease [26-30]. 


\section{Diagnosing Sarcopenia Obesity}

Several anthropometric measures can be done to determine body composition. The most reliable instruments to measure the whole-body and fat-free mass are either Dual-energy X-ray absorptiometry (DXA) or computed tomography (CT) scan on the 3rd lumbar vertebra [31]. CT-scan images provide details on specific muscles, adipose tissues, and organs, not visualized on DXA, thus providing great significance in precision to quantify specific tissues and to predict whole-body composition [31]. CT-scan also offers the highest available precision and specificity in determining muscle mass, fat mass, and distribution. Besides, CT-scan is freely available at the medical record and often used for the diagnostic and evaluative procedure. BIA provides a convenient and cost-effective measurement method by measuring based on the disparate electrical conductivity of fat and lead tissues, commonly described as height adjusted in $\mathrm{kg} / \mathrm{m}^{2}$ [17].

\section{Mechanism of Sarcopenic Obesity}

Loss of muscle mass occurs due to multiple causes and interactions between hormonal changes, aging, disuse, neuronal, poor nutrition, physical inactivity, and low-grade inflammation. This results in a decrease in oxidative capacities, mitochondrial volumes, protein synthesis, proteolysis, neuromuscular integrity disruption, and alteration in the muscle fat content which leads to a decrease in lean mass [15,32-35].

\section{Age}

Both cancer and sarcopenic obesity prevalence are increasing with age [36]. Most cancers are diagnosed in the elderly while, with aging, there will be changes in fat distribution with the distribution preferentially on ectopic areas and visceral organs rather than abdominal subcutaneous tissues. These changes are exacerbated by physical inactivity, hormonal changes including responsiveness to thyroid hormone, and leptin resistance. Intramuscular fat deposition is influenced by the degree of inflammation, mitochondrial dysfunction, and insulin resistance $[37,38]$. Decreased lean mass and increased fat mass increase the risk of chemotherapy toxicity. However, the exact mechanism between chemotherapy toxicity and body composition remains unclear $[4,39]$. Further information can be seen in Figure 2 .

Body metabolism rates undergo several changes to protect the body from the reduction of body weight from aging. This includes reduced energy expenditure due to physical inactivity, alteration in the thermogenic effect of food and muscle, and resting metabolic rate. Reduced muscle mass and adaptive change of metabolism combined with a sedentary lifestyle cause alteration in energy expenditure. These changes contribute to a gradual increase in body fat [15].

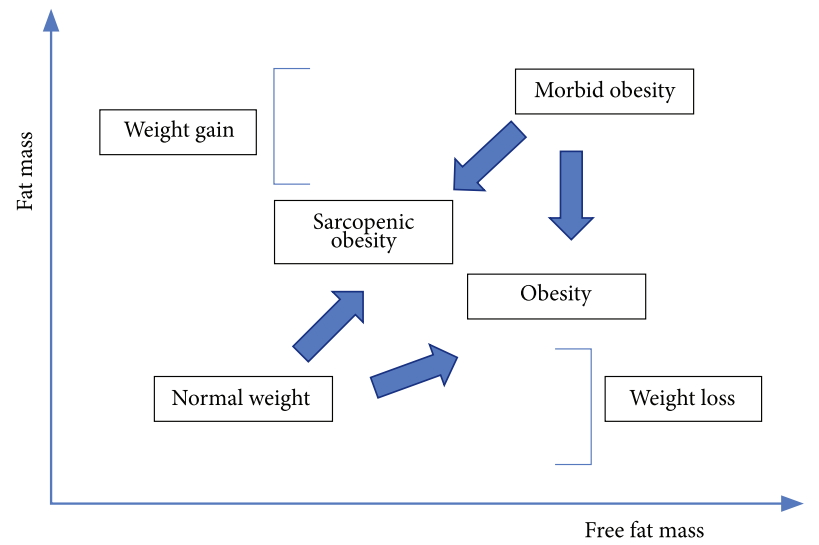

Figure 2. Hypothetical metabolic scenarios of sarcopenic obesity from two different trajectories [11]

\section{Sex Hormones}

Sex hormones also contributes to fat composition in the human body. In women, the visceral area is affected by body weight gain and increased fat mass especially after menopause. Estrogen hormone plays a significant role in modulating inflammation in skeletal muscle through satellite cell activation and reducing fat deposition and muscle loss $[40,41]$.

Testosterone is well known in promoting muscle-cell regeneration through satellite cell activation and increasing muscle protein synthesis by increasing amino acids utilization by muscle cells to develop and increase androgen receptor expression [42-44]. In men, testosterone levels tend to decrease by approximately $1 \%$ every year, which contributes to muscle mass loss and inappropriate fat distribution in the body $[45,46]$. These changes are associated with reduced lean mass, increased level of visceral fat, and obesity.

\section{Inflammation}

The inflammatory pathway also plays a significant role in the alteration of body composition. Obesity is well known for causing increased inflammatory state by activating macrophages, mast cells, and $\mathrm{T}$ lymphocytes to induce secretion of tumor necrosis factor (TNF), leptin, and growth hormone (GH) [47-49]. All such secretory changes lead to insulin resistance which is further increased by muscle cells catabolism, promoting gain in fat mass and loss of muscle mass $[47,50]$. Frailty incidence is increased because of the increased level of leptin which blunts the anabolic effect of insulin and reduces the level of sex hormone [51]. Leptin upregulates the proinflammatory cytokines IL- 6 and TNF and reduces the levels of IGF-1 [52]. Further, the elevated level of TNF inhibits adiponectin which acts to counter the effect of leptin [53]. Obesity also induces leptin resistance and causes reduced muscle fatty oxidation and ectopic fat deposition $[54,55]$. Inflammation has become an 
important hallmark of cancer, as cancer itself is a chronic inflammation [56]. Higher systemic inflammation state is associated with higher metastatic risk and mortality. Several clinical markers, such as neutrophil to lymphocyte ratio (NLR), correlates with other systemic inflammation cytokines and implicates systemic catabolism on various cancers [57]. Systemic inflammation and several cytokines such as tumor necrosis factor and interleukin 6 (IL-6) promote insulin resistance and protein degradation and decrease muscle synthesis. Several mechanisms on systemic inflammation causing insulin resistance and protein degradation have been proposed, one of which is caused by the activation of the ubiquitin-proteasome proteolysis pathway leading to muscle wasting and degradation leading to exacerbation of insulin resistance [57].

\section{Myocellular Mechanism}

Myocellular also plays an important role in reduced muscle strength in sarcopenic patients. Reduced perfusion, low availability of postprandial amino acids, reduced digestive capacity caused by sequestration of amino acids in splanchnic circulation may cause impaired skeletal metabolism owing to the process of aging [58]. As the results of these processes, reduction of muscle mass and strength, reduction of motor neurons, collagen deposition, fat cells infiltration in muscle cells, and fiber necrosis might occur in sarcopenic patients. Deposition of intramyocellular lipids may cause lipo-toxicity to muscle cells and disturbance in muscle-cell regenerative capabilities, impairment in oxidative capabilities, and insulin resistance caused by impairment in mitochondrial fatty acid oxidation [1,59-62]. Also, elevated concentration of fatty acids may cause the deposition of fat cells in the liver, heart, pancreas, and skeletal muscle [15]. Muscle cells tend to store fat more than glucose as proposed by one study which compares healthy men and women aged 18-28 years exposed to 30 days of leg disuse which results in muscle loss but an increase in intramyocellular lipid deposition [63-65]. The intramyocellular fat deposition may also impair muscle cell regeneration as pro-inflammatory cytokines, and hormones are released by lipid cells that interfere with the regenerative capabilities of muscle cells by satellite mesenchymal cells, exacerbating sarcopenia in obese patients $[15,66-70]$. All the mechanisms of sarcopenic obesity are highlighted in Figure $\mathbf{3}$.

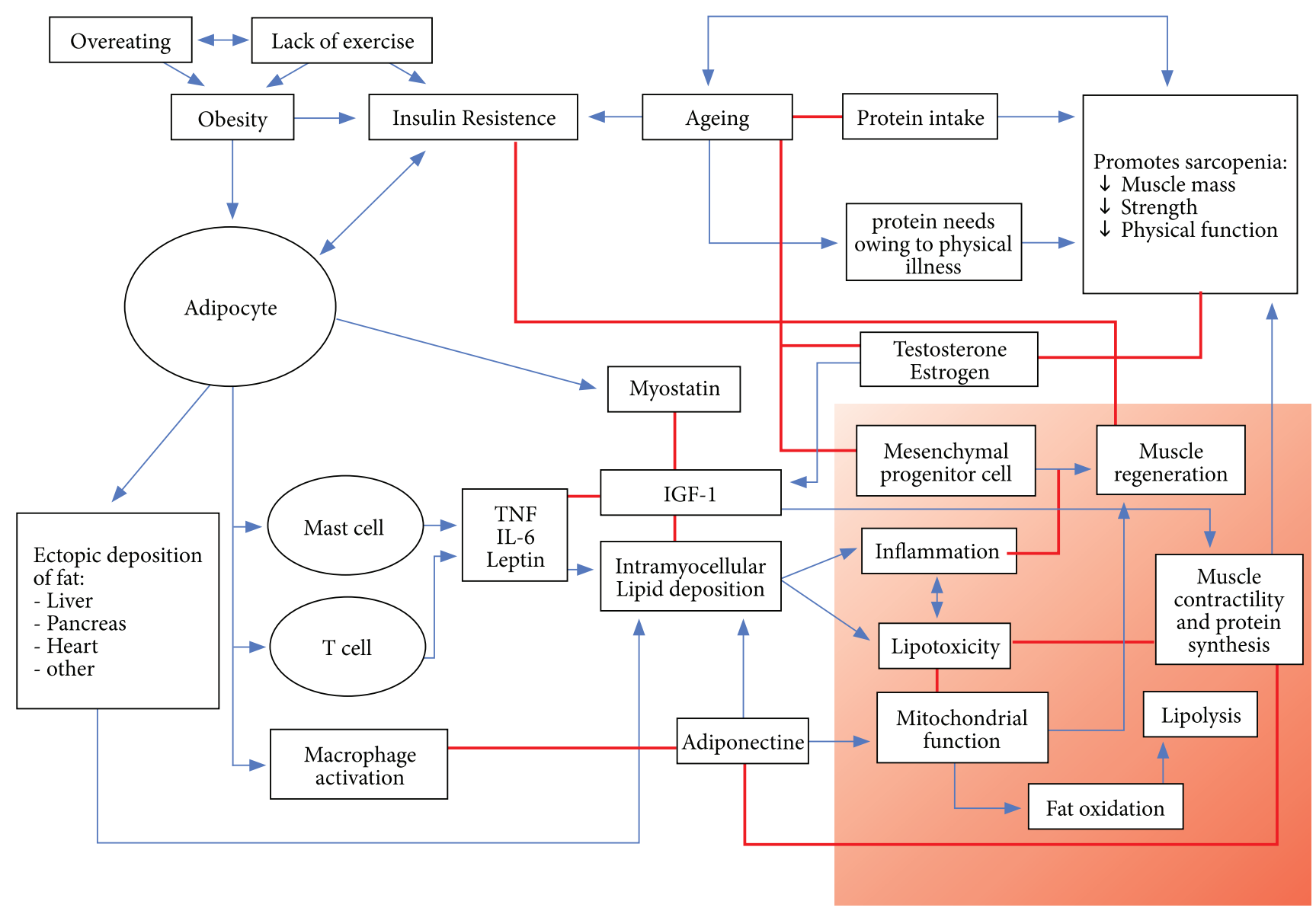

Figure 3. Summary of sarcopenic obesity mechanism [15] 


\section{Impacts of Sarcopenic Obesity in Cancer Patients}

Cancer is one of the leading causes of death, and multimodality treatments are needed to manage patients with cancer. In search of reliable prognostic factors, many physicians focus on tumor-specific factors (TNM/ UICC) rather than taking the patient's specific conditions as their major concern [71]. Body mass is defined as the proportion and distribution of the bone, lean, and fat tissues in the human body that is not easily reflected by the weight-based metrics measurement, especially in cancer patients whose muscle mass does not strongly correlate with BMI or BSA [17].

Sarcopenic obesity alone has a greater prevalence of metabolic syndrome and cardiovascular outcome and has a negative impact on overall survival, dose-limiting toxicity, physical disability, and higher major postoperative complication in cancer patients $[20,72]$. The alteration in body composition also makes an impaired response to chemotherapy and radiation therapy in a variety of cancers, making treatments more difficult in these patients. In a retrospective study of pancreatic cancer patients, sarcopenic obesity is associated with lower overall survival and recurrence-free survival $[7,17,73-78]$

Multiple studies of different cancer patients conclude sarcopenic obesity as an independent risk factor on clinical outcomes and overall survival after surgical resection $[28,79]$. Sarcopenic obesity is also seen as an independent risk factor of mortality in lung, prostate, and GI cancer patients with the locally advanced or metastatic disease $[11,80-83]$. Some authors suggest several mechanisms contributing to these adverse outcomes including impaired immune response and chronic inflammation associated with sarcopenia and obesity that lead patients to the vulnerability of operative stress causing higher rates of surgical site infection and compromising wound healing mechanism and recovery [84-88].

Sarcopenic obesity is also hypothesized to be associated with chemotherapy toxicity caused by a combination of high absolute doses with a reduced volume of distribution and impaired metabolism and clearance of a very depleted lean body mass $[10,11,17]$. Decreased lean mass and increased fat mass causing the risk of chemotherapy toxicity increase as demonstrated in breast cancer patients undergoing chemotherapy. However, the exact mechanism between chemotherapy toxicity and body composition remains unclear [39].

Several chemotherapies have been proposed to induce sarcopenic obesity in cancer patients undergoing chemotherapy treatment. In lung cancer patients receiving cisplatin as chemotherapy, there is a reduction in muscle mass and an increase in fat mass accumulation in viscera. Weight gain during chemotherapy is sometimes misinterpreted as the signs of regaining health, but the change in body composition is often neglected $[89,90]$.

\section{Treatment}

Until now, no medications have been proven to be effective in treating this condition. The key management in treating sarcopenic obesity relies on preserving muscle mass and function by lifestyle modification including the combination of physical activity and dietary changes. Physical exercise may induce anabolism. Thus, protein intake before physical exercise or spreading protein intake throughout the day may provide beneficial effects [15].

\section{Diet}

Acute caloric restriction may induce catabolism and proteolysis which lead to a decline in muscle mass. However, chronic caloric restriction may show opposite effects by increasing muscle protein synthesis and promoting muscle growth. High protein intake should be initiated to ensure adequate protein intake to counter the effect of weight loss-induced sarcopenia in individuals participating in a weight loss program. Higher protein intake for about $1.5 \mathrm{~g} / \mathrm{kg} /$ day is recommended due to high metabolic rates in cancer patients with careful monitoring in renal function. Consumption of high essential amino acids (EAA), found in beef, fish, and peanut, is recommended [91,92].

\section{Physical Exercise}

Physical exercise is recommended in older adults with a sum of 150 minutes per week consisting of moderate to vigorous aerobic exercise training with a minimum of two sessions of resistance training. Resistance training is beneficial in improving muscle mass and strength by focusing on strength training, flexibility, and balance. High-intensity resistance training combined with a short resting interval improves body composition in the elderly [93]. The combination of both diet and physical exercise also shows improvement in the adipose marker and reduced level of leptin, C-reactive protein, and IL-6 [94].

\section{CONCLUSION}

Sarcopenic obesity is a condition where declining muscle mass and function coexist with high-fat mass which leads to lower lean mass. Sarcopenic obesity is related to higher rates of chemotherapy toxicities and mortality in cancer patients which physicians need to pay more attention to. However, this condition is commonly missed because the evaluation of body composition is not a routine procedure. The diagnosis of sarcopenic obesity requires a body composition measurement which is best demonstrated by using CT-scan. Physical exercise in combination with dietary modification is the best strategy to manage sarcopenic obesity in cancer patients. 


\section{DECLARATIONS}

\section{Competing interest}

The authors declare no competing interest in this study.

\section{Acknowledgement}

The authors wish to thank faculty of medicine, Pelita Harapan University for supporting this study to be done.

\section{REFERENCES}

1. Kalinkovich A, Livshits G. Sarcopenic obesity or obese sarcopenia: A cross talk between age-associated adipose tissue and skeletal muscle inflammation as a main mechanism of the pathogenesis. Ageing Res Rev. 2017;35:200-21.

2. Cruz-Jentoft AJ, Bahat G, Bauer J, Boirie $Y$, Bruyère O, Cederholm T, et al. Sarcopenia: Revised European consensus on definition and diagnosis. Age Ageing. 2019;48(1):16-31.

3. Santilli V, Bernetti A, Mangone M, Paoloni M. Clinical definition of sarcopenia. Clin Cases Miner Bone Metab. 2014;11(3):177-80.

4. Polyzos SA, Margioris AN. Sarcopenic obesity. Hormones. 2018;17(3):321-31.

5. Cruz-Jentoft AJ, Bahat $G$, Bauer J, Boirie $Y$, Bruyère O, Cederholm T, et al. Sarcopenia: revised European consensus on definition and diagnosis. Age Ageing. 2019;48(1):16-31.

6. Deluche E, Leobon S, Desport JC, Venat-Bouvet L, Usseglio J, Tubiana-Mathieu N. Impact of body composition on outcome in patients with early breast cancer. Support Care Cancer. 2018;26(3):861-8.

7. Gruber ES, Jomrich G, TamandI D, Gnant M, Schindl M, Sahora K. Sarcopenia and sarcopenic obesity are independent adverse prognostic factors in resectable pancreatic ductal adenocarcinoma. PLoS One. 2019;14(5):e0215915.

8. Lodewick TM, van Nijnatten TJA, van Dam RM, van Mierlo K, Dello SAWG, Neumann UP, et al. Are sarcopenia, obesity and sarcopenic obesity predictive of outcome in patients with colorectal liver metastases? HPB. 2015;17(5):438-46.

9. Antoun S, Borget I, Lanoy E. Impact of sarcopenia on the prognosis and treatment toxicities in patients diagnosed with cancer. Curr Opin Support Palliat Care. 2013;7(4):383-9.

10. Anandavadivelan P, Brismar TB, Nilsson $M$, Johar AM, Martin L. Sarcopenic obesity: A probable risk factor for dose limiting toxicity during neo-adjuvant chemotherapy in oesophageal cancer patients. Clin Nutr. 2016;35(3):724-30.
11. Prado CM, Lieffers JR, McCargar $\amalg$, Reiman T, Sawyer $M B$, Martin L, et al. Prevalence and clinical implications of sarcopenic obesity in patients with solid tumours of the respiratory and gastrointestinal tracts: a population-based study. Lancet Oncol. 2008;9(7):629-35.

12. Goodpaster BH, Park SW, Harris TB, Kritchevsky SB, Nevitt M, Schwartz A V., et al. The Loss of Skeletal Muscle Strength, Mass, and Quality in Older Adults: The Health, Aging and Body Composition Study. Journals Gerontol Ser A Biol Sci Med Sci. 2006;61(10):1059-64.

13. Hughes VA, Roubenoff $R$, Wood $M$, Frontera WR, Evans WJ, Fiatarone Singh MA. Anthropometric assessment of 10-y changes in body composition in the elderly. Am J Clin Nutr. 2004;80(2):475-82.

14. Song M-Y, Ruts E, Kim J, Janumala I, Heymsfield S, Gallagher D. Sarcopenia and increased adipose tissue infiltration of muscle in elderly African American women. Am J Clin Nutr. 2004;79(5):874-80.

15. Batsis JA, Villareal DT. Sarcopenic obesity in older adults: aetiology, epidemiology and treatment strategies. Nat Rev Endocrinol. 2018;14(9):513-37.

16. Meza-Junco J, Montano-Loza AJ, Baracos VE, Prado CMM, Bain VG, Beaumont C, et al. Sarcopenia as a prognostic index of nutritional status in concurrent cirrhosis and hepatocellular carcinoma. J Clin Gastroenterol. 2013;47(10):861-70.

17. Baracos VE, Arribas L. Sarcopenic obesity: Hidden muscle wasting and its impact for survival and complications of cancer therapy. Ann Oncol. 2018;29(Supplement 2):ii1-9.

18. Villareal DT, Apovian CM, Kushner RF, Klein S, American Society for Nutrition, NAASO, The Obesity Society. Obesity in older adults: technical review and position statement of the American Society for Nutrition and NAASO, The Obesity Society. Am J Clin Nutr. 2005;82(5):923-34.

19. Garvey WT, Mechanick JI, Brett EM, Garber AJ, Hurley DL, Jastreboff AM, et al. American association of clinical endocrinologists and American college of endocrinology comprehensive clinical practice guidelines for medical care of patients with obesity. Endocr Pract. 2016;22:1-203.

20. Prado CMM, Wells JCK, Smith SR, Stephan BCM, Siervo M. Sarcopenic obesity: A Critical appraisal of the current evidence. Clin Nutr. 2012;31(5):583-601.

21. Baumgartner RN, Koehler KM, Gallagher D, Romero L, Heymsfield SB, Ross RR, et al. Epidemiology of Sarcopenia among the Elderly in New Mexico. Am J Epidemiol. 1998;147(8):755-63.

22. Janssen I, Heymsfield SB, Ross R. Low Relative Skeletal Muscle Mass (Sarcopenia) in Older Persons Is Associated with Functional Impairment and Physical Disability. J Am Geriatr Soc. 2002;50(5):889-96. 
23. Metter EJ, Talbot LA, Schrager M, Conwit R. Skeletal muscle strength as a predictor of all-cause mortality in healthy men. J Gerontol A Biol Sci Med Sci. 2002;57(10):B359-65.

24. Cosquéric G, Sebag A, Ducolombier C, Thomas C, Piette F, Weill-Engerer $S$. Sarcopenia is predictive of nosocomial infection in care of the elderly. $\mathrm{Br} \mathrm{J}$ Nutr. 2006;96(5):895-901.

25. Pichard C, Kyle UG, Morabia A, Perrier A, Vermeulen $B$, Unger P. Nutritional assessment: lean body mass depletion at hospital admission is associated with an increased length of stay. Am J Clin Nutr. 2004;79(4):613-8.

26. Del Fabbro E, Parsons $\mathrm{H}$, Warneke $\mathrm{CL}$, Pulivarthi $\mathrm{K}$, Litton JK, Dev $R$, et al. The relationship between body composition and response to neoadjuvant chemotherapy in women with operable breast cancer. Oncologist. 2012;17(10):1240-5.

27. Dalal S, Hui D, Bidaut L, Lem K, Del Fabbro E, Crane $C$, et al. Relationships Among Body Mass Index, Longitudinal Body Composition Alterations, and Survival in Patients With Locally Advanced Pancreatic Cancer Receiving Chemoradiation: A Pilot Study. J Pain Symptom Manage. 2012;44(2):181-91.

28. Malietzis G, Currie AC, Athanasiou T, Johns $N$, Anyamene N, Glynne-Jones R, et al. Influence of body composition profile on outcomes following colorectal cancer surgery. Br J Surg. 2016;103(5):572-80.

29. Rier HN, Jager A, Sleijfer S, van Rosmalen J, Kock MCJM, Levin M-D. Low muscle attenuation is a prognostic factor for survival in metastatic breast cancer patients treated with first line palliative chemotherapy. The Breast. 2017;31:9-15.

30. Grotenhuis BA, Shapiro J, van Adrichem S, de Vries M, Koek M, Wijnhoven BPL, et al. Sarcopenia/Muscle Mass is not a Prognostic Factor for Short- and LongTerm Outcome After Esophagectomy for Cancer World J Surg. 2016;40(11):2698-704.

31. Mourtzakis M, Prado CMM, Lieffers JR, Reiman T, McCargar LJ, Baracos VE. A practical and precise approach to quantification of body composition in cancer patients using computed tomography images acquired during routine care. Appl Physiol Nutr Metab. 2008;33(5):997-1006.

32. Cruz-Jentoft AJ, Bahat $G$, Bauer J, Boirie $Y$, Bruyère O, Cederholm T, et al. Sarcopenia: revised European consensus on definition and diagnosis. Age Ageing. 2019;48(1):16-31.

33. Xu W, Perera S, Medich D, Fiorito G, Wagner J, Berger LK, et al. Height loss, vertebral fractures, and the misclassification of osteoporosis. Bone. 2011;48(2):307-11.

34. Sayer AA, Syddall H, Martin H, Patel H, Baylis D, Cooper $\mathrm{C}$. The developmental origins of sarcopenia. J Nutr Health Aging. 2008;12(7):427-32.
35. Conley KE, Esselman PC, Jubrias SA, Cress ME, Inglin $B$, Mogadam C, et al. Ageing, muscle properties and maximal $\mathrm{O}(2)$ uptake rate in humans. J Physiol. 2000;526 Pt 1(Pt 1):211-7.

36. Yancik R. Population Aging and Cancer. Cancer J. 2005;11(6):437-41.

37. Visser $M$, Goodpaster BH, Kritchevsky SB, Newman $A B$, Nevitt M, Rubin SM, et al. Muscle Mass, Muscle Strength, and Muscle Fat Infiltration as Predictors of Incident Mobility Limitations in Well-Functioning Older Persons. Journals Gerontol Ser A Biol Sci Med Sci. 2005;60(3):324-33.

38. Schrauwen-Hinderling VB, Hesselink MKC, Schrauwen $P$, Kooi ME. Intramyocellular Lipid Content in Human Skeletal Muscle. Obesity. 2006;14(3):357-67.

39. Berg MMGA van den, Kok DE, Posthuma $L$, Kamps $L$, Kelfkens CS, Buist $N$, et al. Body composition is associated with risk of toxicity-induced modifications of treatment in women with stage I-IIIB breast cancer receiving chemotherapy. Breast Cancer Res Treat. 2019;173(2):475.

40. Enns DL, Tiidus PM. Estrogen influences satellite cell activation and proliferation following downhill running in rats. J Appl Physiol. 2008;104(2):347-53.

41. Gambacciani M, Ciaponi M, Cappagli B, De Simone L, Orlandi R, Genazzani AR. Prospective evaluation of body weight and body fat distribution in early postmenopausal women with and without hormonal replacement therapy. Maturitas. 2001;39(2):125-32.

42. Kadi F. Cellular and molecular mechanisms responsible for the action of testosterone on human skeletal muscle. A basis for illegal performance enhancement. Br J Pharmacol. 2008;154(3):522-8.

43.43. Bondanelli $M$, Ambrosio $M R$, Margutti $A$, Franceschetti $\mathrm{P}$, Zatelli MC, degli Uberti EC. Activation of the Somatotropic Axis by Testosterone in Adult Men: Evidence for a Role of Hypothalamic Growth Hormone-Releasing Hormone. Neuroendocrinology. 2003 Jun;77(6):380-7.

44. Urban RJ, Bodenburg YH, Gilkison C, Foxworth J, Coggan AR, Wolfe RR, et al. Testosterone administration to elderly men increases skeletal muscle strength and protein synthesis. Am J Physiol Metab. 1995;269(5):E820-6.

45. LeBlanc ES, Wang PY, Lee CG, Barrett-Connor E, Cauley JA, Hoffman AR, et al. Higher Testosterone Levels Are Associated with Less Loss of Lean Body Mass in Older Men. J Clin Endocrinol Metab. 2011;96(12):3855-63.

46. Miller KK. Androgen deficiency: effects on body composition. Pituitary. 2009;12(2):116-24.

47. Schrager MA, Metter EJ, Simonsick E, Ble A, Bandinelli $S$, Lauretani $F$, et al. Sarcopenic obesity and inflammation in the InCHIANTI study. J Appl Physiol. 2007;102(3):919-25. 
48. Forsythe LK, Wallace JMW, Livingstone MBE. Obesity and inflammation: the effects of weight loss. Nutr Res Rev. 2008;21(2):117-33.

49. Park HS, Park JY, Yu R. Relationship of obesity and visceral adiposity with serum concentrations of CRP, TNF- $\alpha$ and IL-6. Diabetes Res Clin Pract. 2005;69(1):29-35.

50. Zamboni M, Mazzali G, Fantin F, Rossi A, Di Francesco V. Sarcopenic obesity: A new category of obesity in the elderly. Nutr Metab Cardiovasc Dis. 2008;18(5):388-95.

51. Yeap BB, Paul Chubb SA, Lopez D, Ho KKY, Hankey GJ, Flicker L. Associations of insulin-like growth factor-I and its binding proteins and testosterone with frailty in older men. Clin Endocrinol (Oxf). 2013;78(5):752-9.

52. Hamrick MW. Role of the Cytokine-like Hormone Leptin in Muscle-bone Crosstalk with Aging. J bone Metab. 2017;24(1):1-8.

53. Wang Y, Wang $X$, Lau WB, Yuan Y, Booth D, Li J-J, et al. Adiponectin Inhibits Tumor Necrosis Factor- $\alpha-$ Induced Vascular Inflammatory Response via Caveolin-Mediated Ceramidase Recruitment and Activation. Circ Res. 2014;114(5):792-805.

54. Shulman GI. Ectopic Fat in Insulin Resistance, Dyslipidemia, and Cardiometabolic Disease. N Engl J Med. 2014;371(12):1131-41.

55. Cartwright M, Tchkonia T, Kirkland J. Aging in adipocytes: Potential impact of inherent, depot-specific mechanisms. Exp Gerontol. 2007;42(6):463-71.

56. Coussens LM, Werb Z. Inflammation and cancer. Nature. 2002;420(6917):860-7.

57. Feliciano EMC, Kroenke $\mathrm{CH}$, Meyerhardt JA, Prado $\mathrm{CM}$, Bradshaw PT, Kwan ML, et al. Association of Systemic Inflammation and Sarcopenia With Survival in Nonmetastatic Colorectal Cancer: Results From the C SCANS Study. JAMA Oncol. 2017;3(12):e172319.

58. Stenholm S, Harris TB, Rantanen T, Visser $M$, Kritchevsky SB, Ferrucci L. Sarcopenic obesity: definition, cause and consequences. Curr Opin Clin Nutr Metab Care. 2008;11(6):693-700.

59. Kob R, Bollheimer LC, Bertsch T, Fellner C, Djukic M, Sieber CC, et al. Sarcopenic obesity: molecular clues to a better understanding of its pathogenesis? Biogerontology. 2015;16(1):15-29.

60. Stinkens R, Goossens GH, Jocken JWE, Blaak EE. Targeting fatty acid metabolism to improve glucose metabolism. Obes Rev. 2015;16(9):715-57.

61. Aon MA, Bhatt N, Cortassa SC. Mitochondrial and cellular mechanisms for managing lipid excess. Front Physiol. 2014;5:282.

62. Bruce CR, Anderson MJ, Carey AL, Newman DG, Bonen A, Kriketos $A D$, et al. Muscle Oxidative Capacity Is a Better Predictor of Insulin Sensitivity than Lipid Status. J Clin Endocrinol Metab. 2003;88(11):5444-51.
63. Manini TM, Clark BC, Nalls MA, Goodpaster BH, Ploutz-Snyder LL, Harris TB. Reduced physical activity increases intermuscular adipose tissue in healthy young adults. Am J Clin Nutr. 2007;85(2):377-84.

64. Kusminski CM, Shetty S, Orci L, Unger RH, Scherer PE. Diabetes and apoptosis: lipotoxicity. Apoptosis. 2009;14(12):1484-95.

65. Nilsson MI, Dobson JP, Greene NP, Wiggs MP, Shimkus KL, Wudeck E V., et al. Abnormal protein turnover and anabolic resistance to exercise in sarcopenic obesity. FASEB J. 2013;27(10):3905-16.

66. Carnio S, LoVerso F, Baraibar MA, Longa E, Khan MM, Maffei $M$, et al. Autophagy Impairment in Muscle Induces Neuromuscular Junction Degeneration and Precocious Aging. Cell Rep. 2014;8(5):1509-21.

67. Marcell TJ. Sarcopenia: causes, consequences, and preventions. J Gerontol A Biol Sci Med Sci. 2003;58(10):M911-6.

68. Wohlgemuth SE, Seo AY, Marzetti E, Lees HA, Leeuwenburgh C. Skeletal muscle autophagy and apoptosis during aging: Effects of calorie restriction and life-long exercise. Exp Gerontol. 2010;45(2):138-48.

69. Shefer G, Rauner G, Stuelsatz P, Benayahu D, Yablonka-Reuveni Z. Moderate-intensity treadmill running promotes expansion of the satellite cell pool in young and old mice. FEBS J. 2013;280(17):4063-73.

70. Zwetsloot KA, Childs TE, Gilpin LT, Booth FW. Nonpassaged muscle precursor cells from 32-month old rat skeletal muscle have delayed proliferation and differentiation. Cell Prolif. 2013;46(1):45-57.

71. Åkerberg D, Ansari D, Andersson R. Re-evaluation of classical prognostic factors in resectable ductal adenocarcinoma of the pancreas. World J Gastroenterol. 2016;22(28):6424.

72. Heidelberger V, Goldwasser F, Kramkimel N, Jouinot A, Huillard O, Boudou-Rouquette $P$, et al. Sarcopenic overweight is associated with early acute limiting toxicity of anti-PD1 checkpoint inhibitors in melanoma patients. Invest New Drugs. 2017;35(4):436-41.

73.Joglekar S, Nau PN, Mezhir JJ. The impact of sarcopenia on survival and complications in surgical oncology: A review of the current literature. J Surg Oncol. 2015;112(5):503-9.

74. Levolger S, van Vugt JLA, de Bruin RWF, IJzermans JNM. Systematic review of sarcopenia in patients operated on for gastrointestinal and hepatopancreatobiliary malignancies. $\mathrm{Br} J$ Surg. 2015;102(12):1448-58.

75. Davis MP, Panikkar R. Sarcopenia associated with chemotherapy and targeted agents for cancer therapy. Ann Palliat Med. 2019;8(1):86-101.

76. Okumura S, Kaido T, Hamaguchi Y, Kobayashi A, Shirai H, Yao S, et al. Visceral Adiposity and Sarcopenic Visceral Obesity are Associated with Poor Prognosis After Resection of Pancreatic Cancer. Ann Surg Oncol. 2017;24(12):3732-40. 
77. Daly LE, Ní Bhuachalla ÉB, Power DG, Cushen SJ, James K, Ryan AM. Loss of skeletal muscle during systemic chemotherapy is prognostic of poor survival in patients with foregut cancer. J Cachexia Sarcopenia Muscle. 2018;9(2):315-25.

78. Carneiro IP, Mazurak VC, Prado CM. Clinical Implications of Sarcopenic Obesity in Cancer. Curr Oncol Rep. 2016;18(10):62.

79. Pecorelli N, Carrara G, De Cobelli F, Cristel G, Damascelli A, Balzano G, et al. Effect of sarcopenia and visceral obesity on mortality and pancreatic fistula following pancreatic cancer surgery. Br J Surg. 2016;103(4):434-42.

80. Tan BHL, Birdsell LA, Martin L, Baracos VE, Fearon $\mathrm{KCH}$. Sarcopenia in an overweight or obese patient is an adverse prognostic factor in pancreatic cancer. Clin Cancer Res. 2009;15(22):6973-9.

81. Rollins KE, Tewari N, Ackner A, Awwad A, Madhusudan $S$, Macdonald IA, et al. The impact of sarcopenia and myosteatosis on outcomes of unresectable pancreatic cancer or distal cholangiocarcinoma. Clin Nutr. 2016;35(5):1103-9.

82. Palmela C, Velho S, Agostinho L, Branco F, Santos $M$, Santos MPC, et al. Body composition as a prognostic factor of neoadjuvant chemotherapy toxicity and outcome in patients with locally advanced gastric cancer. J Gastric Cancer. 2017;17(1):74-87.

83. Cushen SJ, Power DG, Murphy KP, McDermott R, Griffin BT, Lim M, et al. Impact of body composition parameters on clinical outcomes in patients with metastatic castrate-resistant prostate cancer treated with docetaxel. Clin Nutr ESPEN. 2016;13:e39-45.

84. Malietzis G, Johns N, Al-Hassi HO, Knight SC, Kennedy $\mathrm{RH}$, Fearon $\mathrm{KCH}$, et al. Low Muscularity and Myosteatosis Is Related to the Host Systemic Inflammatory Response in Patients Undergoing Surgery for Colorectal Cancer. Ann Surg. 2016;263(2):320-5.

85. Sandini $M$, Bernasconi DP, Fior D, Molinelli $M$, Ippolito D, Nespoli L, et al. A high visceral adipose tissue-to-skeletal muscle ratio as a determinant of major complications after pancreatoduodenectomy for cancer. Nutrition. 2016;32(11-12):1231-7.
86. Nishigori T, Tsunoda S, Okabe H, Tanaka E, Hisamori $\mathrm{S}$, Hosogi $\mathrm{H}$, et al. Impact of Sarcopenic Obesity on Surgical Site Infection after Laparoscopic Total Gastrectomy. Ann Surg Oncol. 2016;23(S4):524-31.

87. Srikanthan P, Hevener AL, Karlamangla AS. Sarcopenia Exacerbates Obesity-Associated Insulin Resistance and Dysglycemia: Findings from the National Health and Nutrition Examination Survey III. Earnest CP, editor. PLoS One. 2010;5(5):e10805.

88. Pierpont YN, Dinh TP, Salas RE, Johnson EL, Wright TG, Robson MC, et al. Obesity and Surgical Wound Healing: A Current Review. ISRN Obes. 2014;2014:1-13.

89. Stanisavljevic NS, Marisavljevic DZ. Weight and body composition changes during R-CHOP chemotherapy in patients with non-Hodgkin's lymphoma and their impact on dose intensity and toxicity. J BUON. 15(2):290-6.

90. Nattenmüller J, Wochner R, Muley T, Steins M, Hummler S, Teucher B, et al. Prognostic Impact of CT-Quantified Muscle and Fat Distribution before and after First-Line-Chemotherapy in Lung Cancer Patients. Singh PK, editor. PLoS One. 2017;12(1):e0169136.

91. Kurniawan A. Sarcopenia in Cancer Patients. Indones J Cancer. 2019;13(3):96.

92. Montero-Fernández N, Serra-Rexach JA. Role of exercise on sarcopenia in the elderly. Eur J Phys Rehabil Med. 2013;49(1):131-43.

93. Villanueva MG, Lane CJ, Schroeder ET. Short rest interval lengths between sets optimally enhance body composition and performance with 8 weeks of strength resistance training in older men. Eur J Appl Physiol. 2015;115(2):295-308.

94. Villareal DT, Miller B V, Banks M, Fontana L, Sinacore $D R$, Klein S. Effect of lifestyle intervention on metabolic coronary heart disease risk factors in obese older adults. Am J Clin Nutr. 2006;84(6):1317-23. 